\title{
The Current Practices and Gaps in Forest Accounting System of Ethiopia: A Review
}

\author{
Hundessa Adugna Yadeta* \\ Central Ethiopia Environment and Forest Research Center \\ PO box 33042, Addis Ababa, Ethiopia \\ Alemayehu Negassa Ayana \\ Ethiopian Environment and Forest Research Institute \\ PO box 24536 Code 1000, Addis Ababa, Ethiopia
}

\begin{abstract}
The SNA provides a framework and a comprehensive set of concepts, definitions and classifications for economic accounting that allows compiling, and presenting economic data in a format designed for purposes of economic analysis, decision-making and policymaking. However, the framework is inadequate to be better indicator economic performance, since it misses most of non-marketed economic activities because of different reasons. In this paper, we assessed the gap in the current practices of SNA in general and forest resource accounting system in particular using different national data sources to review the current practice of accounting in Ethiopian Economy. We also examined structure and contents of economic values of forest products and services. In the current Ethiopian system of national accounts, there was attempt to incorporate more forestry economic activities as much as the methodological approaches permitted. Different data on gross value of outputs and cost of material inputs collected from all available sources to calculate the contribution of different economic sectors to Ethiopian GDP. However, there are limitations in full coverage of forest goods and services and up-to-date productivity indicators - calling for a robust effort by all stakeholders. SNA's room for flexibility that allows application of satellite accounting is worthy of value addition for improving the existing SNA gaps in methodologies, data availability and economic activity coverage. Measuring forest values that is more comprehensive than the current SNA greatly contributes towards production of integrated statistical indicators for development plan \& policy formulation in social, economic \& environmental spheres.
\end{abstract}

Keywords: SNA, GDP, Forest Goods and Services, ISIC, Gaps

DOI: $10.7176 /$ RJFA/11-19-06

Publication date:October $31^{\text {st }} 2020$

\section{Introduction}

Ethiopia is a natural resource dependent country. Industries and households in Ethiopia use ecosystem services from forest resources available in the country. Forest ecosystem services are the benefits people obtain from forest resources including provisioning services; regulating services; supporting services; and cultural services (Mäler et al., 2011; Mullan, 2014; Masiero, et al., 2019). This indicates an assessment of its available resources for the sustainable use, and facilitating the formulation of effective and integrated environmental and economic policies related to forest resources (Sisay, et.al, 2010).

National income accounting concept classified forest products as products for use by processing industries; products for final consumption by households; and services of forests used by other industries (Sisay et al., 2010; UNEP, 2016). Forest goods and services used in the industry are already accounted in the GDP, but those forest goods and services consumed by households were not commonly accounted in the GDP. Thus, it needs an adjustment to the national economic accounting system to incorporate the value of such forest products consumed by households or non-marketed forest services used by other sectors in the economy. This requires a close examination of the current GDP accounting system to identify which forest products are already accounted and which ones are not or having gaps in the methods of GDP accounting system (FAO, 2014; UNEP, 2016).

Forest resource accounting aims to fill the gap in national income accounting by calculating \& recording the extent of possible losses or gains of a forest resources and integrate them into the System of National Accounts (SNA). Thus, proper forest accounting ensures that we need to consider natural resource extraction as depreciation instead of being value-added expression (Narita D, et.al., 2018). The gap between the conventional GDP and the adjusted GDP quantifies the extent of depletion and degradation and therefore serves as a signal of the importance of environmental effects. However, the estimate of adjusted GDP should be conceptually consistent with the contemporary system of national accounts.

Developing robust forest accounting procedure that include all forest goods and services serves as better indicators of sustainable development. It is also useful to design more coordinated and effective national development policies that also integrate forest environmental resources (Ramachandra et.al., 2017; Narita D, et.al., 2018). The proper forest accounting system reveals the extent of other sectors' dependence on forests, helps to 
build strategic alliances with other sectors, such as agriculture, tourism, hydroelectricity, water and fishery (FAO, 2004).

Forest resources provide intermediate inputs to other activities, such as livestock grazing and tourism, but the value of these inputs is not recognized (UNEP, 2016; Narita D, et.al., 2018). As a result, our study assessed the gap in the current practices of forest resource accounting system that enables us to call for developing the robust accounting system that measures both the direct and indirect economic contribution of forest resources to national economy of Ethiopia. We used different national data sources to get relevant information about the current practices in Ethiopian national income accounting. Using the current accounting documents, we reviewed the current practice of accounting in Ethiopian economy and examined its structure contents about economic values of forest products and services. We also used different internationally accepted accounting documents to determine the gaps in the current practices of Ethiopian system of national accounts, in accounting of forest resources. We conducted critical analysis on different relevant literature, forest sector statistics, economic reports at micro and macro-levels about forest products and service flow in the economy to clearly identify the gaps and indicate the way forward.

\section{The Systems of National Accounts versus Forest Resource Accounting}

National income accounting is a method of collecting, organising and reporting desirable information on economic activity, which can assist in the measurement of trends and decision-making. It follows internationally agreed concepts, definitions, classifications and accounting methods. System of national accounts (SNA) is the standard way of collecting and compiling data on economic activities both as flow and as stock variables (EU, et.al, 2009; Badura T, et.al. 2017; Hundessa A, 2017). SNA is internationally agreed standard set of recommendations on how to compile measures of economic activity in accordance with strict accounting conventions based on economic principles. Gross Domestic product (GDP) is the most important concept in SNA (EU, et.al, 2009). GDP has been key indicators in the economic policy making over the last 50 years with the purpose of providing a database for macroeconomic analysis. It also used as a measure of the economic progress and standard of living of any country (Agrawal A, et.al., 2013; FAO, 2016; Masiero, et al., 2019). The system of national accounts framework provides accounts that are:

a. comprehensive, in that all designated activities and the consequences for all agents in an economy are covered;

b. consistent, because identical values are used to establish the consequences of a single action on all parties concerned using the same accounting rules;

c. Integrated, in that the resulting accounts necessarily reflected all the consequences of a single action by one agent, including the impact on measurement of wealth captured in balance sheets.

The basic concepts of the SNA are used to analyze and aggregate the numerous aspects of the elementary actions in the economy. SNA provides a comprehensive and detailed record of the complex economic activities taking place within an economy and of the interaction between the different economic agents, and groups of agents that takes place on markets or elsewhere (EU, et.al, 2009). It is also capable of answering the following important economic questions:

1. Who takes action in the economy? This question gives emphasis to the identification of economic agents. Economic agents are the actors in the economic activity.

2. What do they do? This question refers to the economic transactions and other economic flows and stocks. These are considered as the objects of the economy.

3. Why do they take action? This question focuses on the classifications by purposes of expenditure in the economic system.

4. How are the actions known? This gives emphasis to the recording of who, what and why in the economic system. To answer this question, we use Accounting rules of recording, valuation, consolidation and netting.

The System of national accounting explains a complex combination of simple links: "Who does what, with whom, in exchange for what, by what means, for what purpose, with what changes in stocks?" The SNA measures what takes place in the economy, between which agents, and for what purpose. At the heart of the SNA is the production of goods and services (EU, et.al, 2009).

The system of national accounts (SNA) provides a framework and a comprehensive set of concepts, definitions and classifications for National/Regional economic accounting. The SNA framework allows compiling, and presenting economic data in a format designed for purposes of economic analysis, decision-making and policymaking. The accounts themselves present in a condensed way a great mass of detailed information, organized according to economic principles and perceptions, about the working of an economy (UN, 2008; EU, et.al, 2009). More specifically, the four points summarized uses of SNA are monitoring the behavior of the economy, Economic analysis and research, Economic policy making and decision making, and International/ regional comparisons.

For all economic flows, stocks, and all operators in a given economy, in a given period, providing an 
enormous amount of information describing the complete network of economic interrelations. Because, they may be used for consumption in the period to which the accounts relate or may be accumulated for use in a later period. In simple terms, the amount of value added generated by production represents GDP. The income corresponding to GDP is distributed to the various agents or groups of agents as income and it is the process of distributing and redistributing income that allows one agent to consume the goods and services produced by another agent or to acquire goods and services for later consumption. The way in which the SNA captures this pattern of economic flows is to identify the activities concerned by recognizing the institutional units in the economy and by specifying the structure of accounts capturing the transactions relevant to one stage or another of the process by which goods and services are produced and ultimately consumed (UN, 2008; EU, et.al, 2009).

The current measures of national income (SNA) used by different countries of the world, is inadequate as indicator of social welfare. It provides misleading information about whether an economy is using its resources sustainably because there are many limitations on the current system of national accounting to include the contribution of forest products to national income. It is difficult to quantify the benefits from forest ecosystem services since the data availability on natural resources in many developing countries is rather weak. The current accounting system (SNA) view the relationship between the environmental resources and the economy only from economic perspective, because of focusing on goods and services that are bought and sold in markets and ignored the non-marketed services (Badura T, et.al., 2017). Some marketed forest goods and services are accounted into other sectors, e.g. industry, agriculture, energy. (Narita D, et.al., 2018; Masiero, et al., 2019).

In the current system of national accounts, there is inconsistent treatment of manmade and natural assets. It allows depreciation allowance for manmade assets, but the contribution of environmental assets to economy are not valued and thus, but makes no depreciation for these assets (Hundessa A, 2017; Narita D, et.al., 2018). Current GDP considers the depletion and degradation of environmental resources such as forests as increases in income, while this depletion and degradation can in fact have negative consequences to the economy in the future. For example, when forests are transferred for non-forest purposes, the national accounts record only the expenditure incurred in clear felling the forests, and do not account for the loss to society as a result of this transfer. As a result, this accounting procedure did not rightly inform the policy-makers on the important link between economic growth and the environment. Therefore, there is a need for balancing the economic growth and the environment (Green Growth) with recent rapid economic growth. This has received greater recognition in "Climate Resilient Green Economy Strategy" (MEFCC, 2016a; MEFCC, 2016b; UNDP, 2017). This is very important since proper environmental resource accounting is useful for both economy and sustainable environmental resource management, in the countries having renewable natural resources like forests supporting the livelihoods of millions of people. Having comprehensive forest accounting will help achieving more sustainable income without extensive natural resource depletion (UNDP, 2017; Narita D, et.al., 2018).

Forest resource accounting uses to calculate \& record the extent of possible losses or gains of a forest and integrate them into the System of National Accounts (SNA). Thus, proper forest accounting ensures that the system of national accounts no longer consider the natural resource extraction under value-added but as depreciation (Narita D, et.al., 2018). The gap between the conventional GDP and the adjusted GDP quantifies the extent of depletion and degradation and therefore serves as a signal of the importance of environmental effects. However, the estimate of adjusted GDP should be conceptually consistent with the contemporary system of national accounts.

Developing robust forest accounting procedure serves as better indicators of sustainable development that include forest goods and services. It is also useful to design more coordinated and effective national development policies that also integrate forest environmental resources (Ramachandra et.al., 2017; Narita D, et.al., 2018). The proper forest accounting system reveals the extent of other sectors' dependence on forests, helps to build strategic alliances with other sectors, such as agriculture, tourism, hydroelectricity, water and fishery (FAO, 2004). Forest resources provide intermediate inputs to other activities, such as livestock grazing and tourism, but the value of these inputs is not recognized (UNEP, 2016; Narita D, et.al., 2018).

There are two approaches to forest resource accounting: resource based and ecosystem based. However, the existing accounting systems differ not only in what they account, but also on the methods of accounting.

The resource-based approach: follows system of environmental economic accounting central framework (SEEA-CF) \& accounts for individual components like forest lands, trees and major forest products regardless of their source (e.g. timber from forests \&other lands) and mainly focuses on forest lands \& forest products with well-known or potential market values (UN, 2014; Badura et.al., 2017).

The ecosystem-based approach: on the other hand, follows SEEA Experimental Ecosystem Accounting framework \& treats forests as integrated ecosystem (UN, 2014; Masiero, et al., 2019). SEEA Experimental Ecosystem Accounting is a coherent \& integrated approach that considers an environment as a system capable of self-regeneration and degradation. It goes beyond other approaches to ecosystem analysis and attempts to link ecosystems to economic and other human activities explicitly (Badura et.al, 2017; Masiero, et al., 2019). It needs to see the links both in terms of the services provided by ecosystems and in the impacts, economic and other human activities may have on ecosystems and their future capacity (Comberti, et.al, 2015). It tries to capture \& account 
all forest products and services including products \& services with no known values.

The monetary accounting calculates the value of physical assets in monetary terms using various valuation mechanisms like net price method. However, there are no fits for all accounting procedures or methods used to reconcile existing discrepancies. Thus, countries often adapt an international framework and customize it to their respective contexts.

\section{Classification of forest goods and services}

According to Millennium Ecosystem Assessment, (MEA, 2005) forest products can be classified based on the ecosystem service they deliver (US EPA, 2015; Masiero, et al., 2019). The forest ecosystem services are:

1. Provisioning services- Direct use value: The whole of the human economy is driven from the goods and services provided by ecosystems and natural resources. The role that an ecosystem plays in providing any one of goods is termed a 'provisioning service': fuel wood, forest coffee, honey, bees wax, gum and incense, wild foods, spices, bamboo, traditional pharmaceutical products and livestock fodder.

2. Regulating services (Indirect use value): Regulating services either act as final ecosystem services or contribute significantly to final ecosystem services (UK national ecosystem assessment: Technical report): climate regulation, hazard regulation, disease and pest regulation, pollination, noise regulation, soil quality regulation, air quality regulation, and water quality regulation.

3. Cultural services (Direct and Existence value): Cultural services - non-material well-being benefits that people gain from ecosystems (Mullan, 2014; Sing et al., 2015). Such as forest recreational or benefits or their role in religion and environmental education (Thorsen et al., 2014): Health, Nature/ landscape connectionHabitat, Education and learning, Economy, Tourism, Social development and connection, Symbolic, cultural and spiritual significance, Aesthetic and amenity values - refresh, cool and green places (Mullan, 2014; Sing et al., 2015).

4. Supporting services: Supporting services are ecosystem processes that support and underpin provisioning, regulating and cultural services (Mullan, 2014; Sing et al., 2015).

Primary production- The fixation of carbon dioxide by photosynthesis produces organic matter, resulting in plant growth and oxygen production.

Soil formation- The breakdown of the underlying geology by roots and microbial fauna (mineral weathering) and the accumulation of organic matter from leaf litter within the soil layer.

Nutrient cycling- Trees enhance the cycling of nutrients between the leaf litter and the soil, as well as the interception of atmospheric compounds by the canopy,

Water cycle- forests have an important role in the wider hydrological cycle through moisture interception and transpiration.

Biodiversity- providing habitats for pollinators and belowground flora and fauna that maintain the decomposition processes underpinning soil formation and nutrient cycling.

Estimation of Gross Value Added from Forestry, logging and related services. An overview of Ethiopian system of national accounts

Classification Framework - ISIC

International Standard Industrial Classification of All Economic Activities Revision 4 is a coherent and consistent classification structure of economic activities based on a set of internationally agreed concepts, definitions, principles and classification rules. It is a comprehensive framework for economic data collection, reporting, economic analysis, decision-making and policy-making. ISIC provides a continuing flow of information to monitoring, analysis \& evaluation of the economic performance over time. It covers productive activities, (within the production boundary of the SNA) which is hierarchical, four-level structure of mutually exclusive categories - for international comparison in a standardized way. It is a tool for socio-economic and environmental statistics that need to be arranged in accordance with the productive system of the economy and viewed as an effective tool for the harmonization of economic statistics (UN, 2008; Hundessa A, 2017).

ISIC is developed with rigorous consultation and collaboration among all stakeholders - national statistical offices, international organizations, academia and others. It needs to be utilized as the basis for developing National Industrial Classifications (NIC). The scope of ISIC in general covers productive activities, i.e., economic activities within the production boundary of the System of National Accounts (SNA). A few exceptions have been made to allow for the classification of activities beyond the production boundary but which are of importance for various other types of statistics (UN, 2008). Forest products are grouped as Forestry and logging under 'Division 02' of International Standard Industrial Classification of All Economic Activities Revision 4 under Broad and detailed structure as stated in the follows table. 
Table 1: ISIC classification of economic contribution of Forestry and Logging Activity.

\begin{tabular}{|c|c|c|c|}
\hline Division & Group & Class & Description \\
\hline \multirow[t]{5}{*}{ Division 02} & & & Forestry and logging \\
\hline & 021 & 0210 & Silviculture and other forestry activities \\
\hline & 022 & 0220 & Logging \\
\hline & 023 & 0230 & Gathering of non-wood forest products \\
\hline & 024 & 0240 & Support services to forestry \\
\hline
\end{tabular}

\section{Definition and Activity Coverage}

As defined in ISIC Rev 4, the production boundary of forestry and logging Activities include the production of round wood for the forest-based manufacturing industries as well as the extraction and gathering of wild growing non-wood forest products. Besides the production of timber, forestry activities result in products that undergo little processing, such as fire wood, charcoal, wood chips and round wood used in an unprocessed form (e.g. pit-props, pulpwood etc.) - carried out either in natural or planted forests (UN, 2008). The detailed definition and activities grouped under forestry and logging as per the ISIC revision 4 is compiled in the following table. The table shows the context of Ethiopian system of national accounts and identifies the activities included and excluded from GDP due to different reasons such as lack of data and the non-marketability nature of the forest products in the country. Table 2: The accounting status of Forestry and Logging Activities in Ethiopian GDP.

\begin{tabular}{|c|c|c|c|}
\hline Class & Activity & ISIC Included & ided \\
\hline 0210 & $\begin{array}{l}\text { Silviculture } \\
\text { and other } \\
\text { forestry } \\
\text { activities }\end{array}$ & $\begin{array}{l}\text { - Growing of standing timber: } \\
\text { planting, replanting, transplanting, } \\
\text { thinning and conserving of forests } \\
\text { and timber tracts, bamboo, } \\
\text { thatches ... } \\
\text { - Growing of coppice, pulpwood } \\
\text { and fire wood, } \\
\text { - Operation of forest tree nurseries }\end{array}$ & $\begin{array}{l}\text { Activities attributed to other ISIC sectors: } \\
\text { Due to "Production Boundary" definition! } \\
\text { A) Crop Farming: ISIC Group 11-13 (or } \\
\text { Class 0111-0130) } \\
\text { Managed production of any of non-wood } \\
\text { forest products (except growing of cork } \\
\text { trees), (Division 01), Growing of Christmas } \\
\text { trees, (Class 0129), Operation of tree }\end{array}$ \\
\hline 0220 & Logging & $\begin{array}{l}\text { - Production of round wood for } \\
\text { forest-based manufacturing } \\
\text { industries } \\
\text { - Production of round wood used in } \\
\text { an unprocessed form such as pit } \\
\text { props, fence posts and utility } \\
\text { poles, bamboo, thatches... } \\
\text { Gathering and production of fire } \\
\text { - } \begin{array}{l}\text { Pood, } \\
\text { foduction of charcoal in the }\end{array} \\
\text { forest (using traditional methods) }\end{array}$ & $\begin{array}{l}\text { nurseries, (Class 0130), Production of wood } \\
\text { chips and particles, (Class 1610), Growing of } \\
\text { mushrooms or truffles, (0113) and Growing } \\
\text { of berries or nuts, (Class 0125) } \\
\text { B) Forest-based manufacturing } \\
\text { Industries (ISIC Divisions } 16 \text { and 17) } \\
\text { Manufacture of wood and of products of } \\
\text { wood and cork, except furniture; } \\
\text { manufacture of articles of straw and plaiting } \\
\text { materials (Divisions16) and Manufacture of } \\
\text { paper and paper products (Divisions17) }\end{array}$ \\
\hline 0230 & $\begin{array}{l}\text { Gathering } \\
\text { of non- } \\
\text { wood } \\
\text { forest } \\
\text { products }\end{array}$ & $\begin{array}{l}\text { The gathering of non-wood forest } \\
\text { products and other plants growing in } \\
\text { the wild: mushrooms, truffles, berries, } \\
\text { nuts, balata and other rubber-like } \\
\text { gums, cork, lac and resins, balsams, } \\
\text { vegetable hair, eelgrass, acorns, horse } \\
\text { chestnuts, mosses and lichens, Incense } \\
\text { \& myrrh, wild fruits, medicinal } \\
\text { herbs... }\end{array}$ & $\begin{array}{l}\text { - Supply Side: Production of field crops (coffee } \\
\text { cultivation etc.) and Animal fodder, and } \\
\text { extraction of minor and major minerals in } \\
\text { forests, included in agriculture and mining } \\
\text { sectors respectively? Trading in Forestry and } \\
\text { Logging related activities? Public } \\
\text { Administration Services? Entertainment \& } \\
\text { Recreation? etc. }\end{array}$ \\
\hline 0240 & $\begin{array}{l}\text { Support } \\
\text { services to } \\
\text { forestry }\end{array}$ & $\begin{array}{l}\text { - Carrying out part of the forestry } \\
\text { operation on a fee or contract basis. } \\
\text { - Forestry service activities: forestry } \\
\text { inventories, forest management } \\
\text { consulting services, timber } \\
\text { evaluation, forest fire fighting and } \\
\text { protection, forest pest control } \\
\text { - Logging service activities: Transport } \\
\text { of logs within the forest }\end{array}$ & $\begin{array}{l}\text { - Use Side: Forestry contribution to } \\
\text { Consumption Expenditure, Gross Capital } \\
\text { Formation (Investment), Export Earnings, } \\
\text { Domestic Savings? Domestic Revenue? } \\
\text { Contribution in other Microeconomic } \\
\text { (households and Firms) and Macroeconomic } \\
\text { Spheres. } \\
\text { Environment protection and conservation } \\
\text { Sustainability? }\end{array}$ \\
\hline
\end{tabular}

Source: ISIC Rev. 4 and Ethiopian Plan and Development commission 


\section{Types and Sources of data used in Ethiopian system of national accounts}

Data Types: the types of data used in the system of national accounts in general and Ethiopian SNA to account the forest products in particular are the following.

* Quantity \& Price data: (GVO (Gross value of outputs) of Wood \& Non-Wood Forest Products).

* Quantity and Price data of IC (Material Inputs).

Data Sources: different sources of data are used in collecting quantity and price of both the output and material inputs used in national income accounting. These are primary and/or secondary data, Survey and/or census data, Benchmark and/or yearly data, and Direct and/or indirect data.

Generally, there are three Main Data Source Categories used in the accounting procedure, including Statistical system, Administrative system and Qualitative information. The main sources of data identified for the national income accounting by Plan and Development commission- PDC (previously national plan commission) of Ethiopia are those data obtained from the following data sources.

- Surveys conducted by Central statistical Agency (Household food and consumption expenditure (HHFCE), Manufacturing, Distribution, Trade Services etc.),

- Administrative and Financial Reports of different Institutions like: Ministry of Urban Development and Construction, Ministry of Agriculture, Regional Bureaus of Agriculture, Ethiopian Electric Power Corporation, ethiotelecom, Forest Products Enterprises - like Saw mills \& Joineries, Gum and incense Production and Marketing Enterprises, Investment Agency and regional offices, Ethiopian Revenue and Customs Authority, Engineering estimates of different housing types \& other construction, and

- Different forest related research findings (Food and Agriculture Organization (FAO), Ethiopian Institute of Agricultural Research, Ethiopian Environment and Forest Research Institute, and Farm Africa.

\section{Current Estimation Methodology}

General Methodological Dimensions (depending on the availability of data \& information) used by PDC of Ethiopia are direct and/or Indirect Method, Production (Value Added), Expenditure and/or Income Method and Current (Nominal) Versus Constant (Real) Estimates.

Dimension 1: Current Price Estimates (Mixed Approach): In this dimension, the commission uses Production Approach and expenditure approaches to calculate the national income of the country. The production approach of gross value added is vied as follows.

$$
\begin{aligned}
& \text { GVO (Gross value of outputs) } \\
& =\sum \text { (Quantity * Prices) of respective forest goods and related services }
\end{aligned}
$$

IC (Input Cost) $=\sum$ (Quantity X Prices) expenditures on material and operating expenses (transportation, water, electricity, fuel, minor repairs and maintenance of fixed assets, etc.).

Expenditure Approach: e.g. Annual per capita consumption of Forest Products (with appropriate adjustments to commodity flow approach.

$$
\begin{gathered}
\text { GVA }=\text { GVO }- \text { Intermediate inputs } \\
\text { GVO } \\
\text { (population }) *(\text { annual per person quantity of consumption })
\end{gathered}
$$$$
\text { * (Average Annual Producers' Price). }
$$

$\square$ If purchaser's price is used, apply an assumed TTM to derive Producer's Price).

$\square$ 'Zero imports' assumption while deriving 'domestic' or 'regional supply' concept-otherwise imported amount should be deducted)

IC $=$ an assumed proportion of GVO (5-30\%)

Dimension 2: Constant Price Estimates: Three approaches are used depending on available information:

- Revaluation at base year prices (Conventional Method): (Both GVO \& IC are revalued using base year prices) and (Double Deflation! (i.e. Current Quantity * Base Year Prices)

- Deflation of Current Estimates by appropriate Index number (e.g. CPI)

- Extrapolation of Appropriate Volume Indicators

N.B.: Weighted average prices are recommended where applicable 
The Recent Estimation Results

Figure 1: Average sector contribution to real GDP growth (2010-2017 (about 10\%))

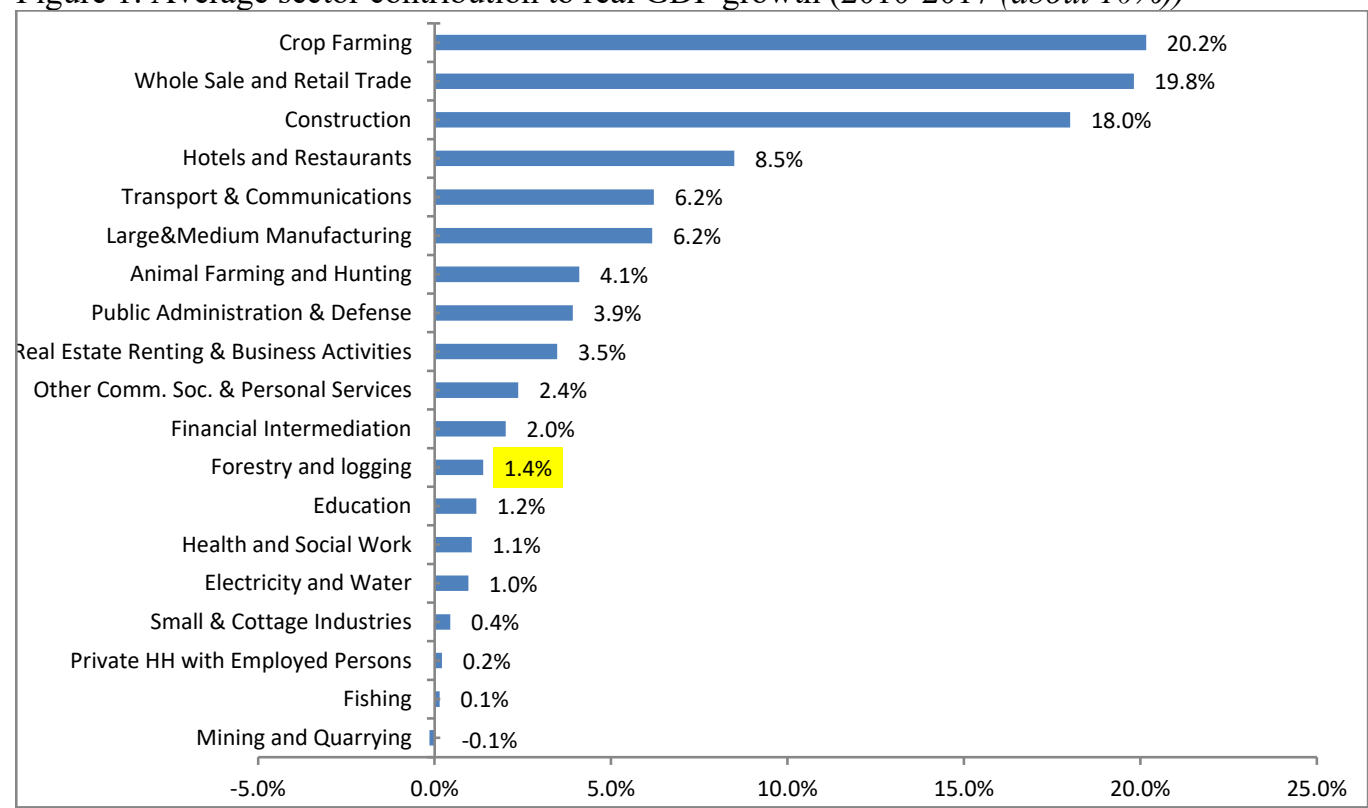

Figure 2: Average \% Share of components of GDP at Current Prices (2010-2017)

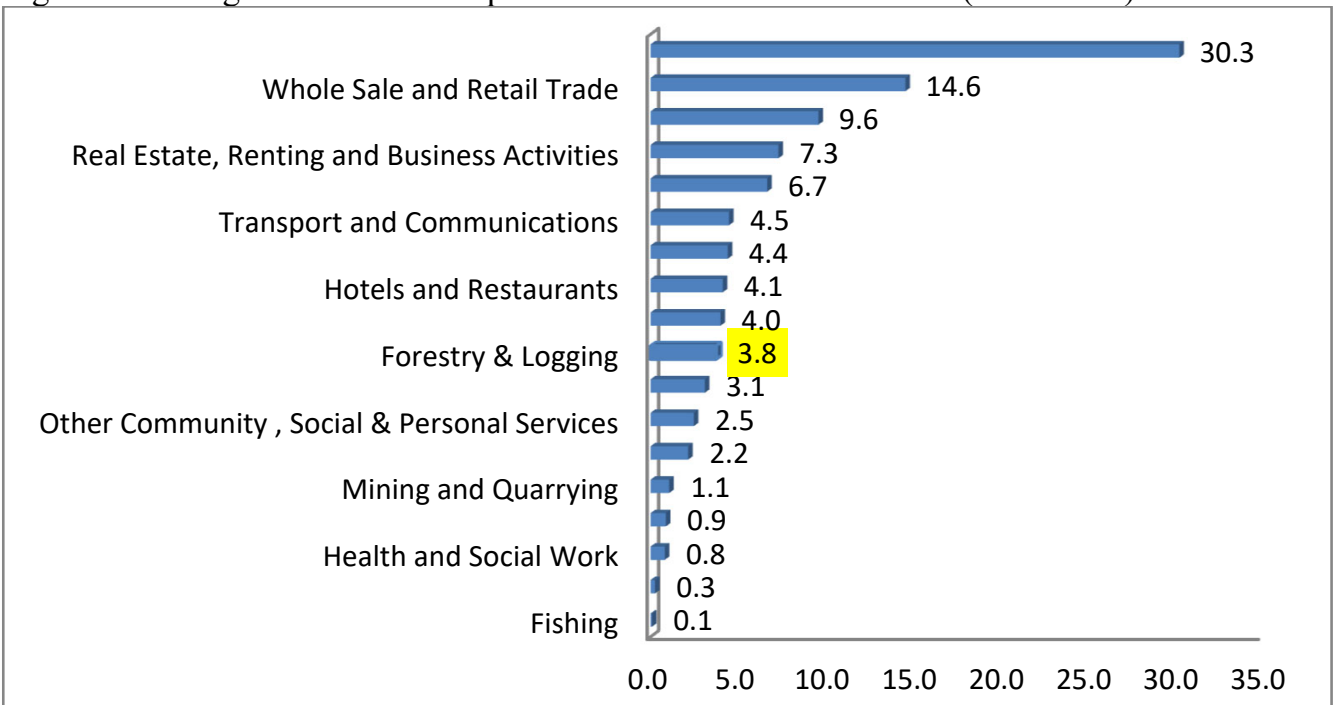

The current Ethiopian system of national accounts needs improvement areas for output and input data. This is because of absence of data/information on forest related activities such as gathering and foraging of wild berries, fruits, seeds, roots and thatching, grass/straw, and collection of medicinal herbs; and services. There is also existence of various and inconsistent indicators on forestry sector activities. Most of production activities of forest products like intermediate consumption of firewood and charcoal. (E.g. used in many industries as inputs like hotels, restaurants, bakeries, through the enterprise surveys) remained unrecorded in Ethiopian economy. The input rates $(5 \%-30 \%$ of gross value of outputs) for the forestry sector are not up-to-date.

In addition, the price levels and deflators (PP and CP Indices) for forest related products and services are not complete. Thus, there is a need for adjustments while using approximation through commodity flow approach (Exports, Imports, IC). Caution in defining production boundaries (Sectorization) while compilation reporting and analysis: Land Clearing for forest development and conservation Activities (currently attributed to Construction sector), Operation of tree nurseries and Crop and Honey products from forest areas (e.g. coffee, honey etc. currently attributed to crop production). Contemporary statistical initiatives go beyond the production of SNANAS to base on integrated statistics approaches - which include among others, 'moving away from a narrow stovepipe statistical production model to cross-functional holistic model'. 


\section{Adjustment to the Gaps in Forest Resource Accounting System}

The current SNA needs adjustment to GDP for nonmarket forest attributes, that is, value of household consumption of all tangible nonmarket forest products and value of household consumption of less-tangible forest amenities.

Adjusted contribution of forest product to GDP = Contribution of forest product accounted in Conventional $G D P+$ Final consumption of all nonmarket forest products + Final consumption of forest amenities (Environmental services) - cost of depletion of forest product.

There is also sectoral adjustment for the contribution of forest products because there are many forest attributes accounted to different economic sectors other than forest. For example, the current SNA overstated the profit in manufacturing sector, because that industry receives free pollution disposal services from forests. Ethiopian SNA also overstated the operating surplus in agriculture since it receives free watershed services from forests. The ecotourism benefits from natural forest and many reserved areas is also accounted for tourism sector. For the above reasons, operating surplus, and therefore, increment of income in forestry is understated. The necessary adjustments needed to adjust for proper accounting of forest products are as follows:

- $\quad$ Adjusted value added in manufacturing = Conventional value added in manufacturing - Value of pollution damage to forests.

- $\quad$ Adjusted value added in agriculture = Conventional value added in agriculture -Value of environmental services provided by forests

- $\quad$ Adjusted value added in Tourism = Conventional value added in Tourism - recreational Value of environmental services provided by forests

Adjusted value added in forestry = Conventional value added in forestry + Value of pollution damage to forests + Value of watershed and other environmental services provided by forests + recreational services provided by forests.

Both economic wide and sector adjustment will increase the contribution of forest product to our national GDP. This will increase the contribution of forest products in GDP.

Total adjustment of value added in forestry = Conventional value added in forestry + Final consumption of nonmarket forest products + Final consumption of amenities and recreational services provided by forests + Value of watershed \& other environmental services to Agriculture - Value of pollution damage to forests - Cost of depletion of forest products.

\section{Conclusion}

The system of national accounts provides a framework and a comprehensive set of concepts, definitions and classifications for National /Regional economic accounting that allows compiling, and presenting economic data in a format designed for purposes of economic analysis, decision-making and policymaking. The accounts themselves present in a condensed way a great mass of detailed information, organized according to economic principles and perceptions, about the working of an economy. However, the framework is inadequate to be better indicator economic performance. As a result, our study assessed the gap in the current practices of forest resource accounting system that enables us indicate the necessity to develop the robust accounting system that measures both the direct and indirect economic contribution of forest resources to national economy of Ethiopia. We used different national data sources to review the current practice of accounting in Ethiopian Economy and examined its structure contents about economic values of forest products and services.

In the current Ethiopian system of national accounts, every attempt is done to incorporate more forestry economic activities as much as the methodological approaches permitted. Different data on gross value of outputs and cost of material inputs collected from all available sources such as Statistical system, administrative system and qualitative information to calculate the contribution of different economic sectors to GDP. However, there are limitations in full coverage of forest goods and services and up-to-date productivity indicators - calling for a robust effort by all stakeholders. SNA's room for flexibility that allows application of satellite accounting is worthy of value addition for improving the existing SNA gaps in methodologies, data availability and economic activity coverage. Measuring forest values that is more comprehensive than the current system of national accounts greatly contributes towards production of integrated statistical indicators for development plan $\&$ policy formulation in social, economic \& environmental spheres.

\section{References}

Arun Agrawal, Ben Cashore, Rebecca Hardin, Gill Shepherd, Catherine Benson and Daniel Miller. (2013). Economic Contributions of Forests. Background paper 1, $10^{\text {th }}$ session. United Nations Forum on Forests. Istanbul, Turkey.

Badura T., Ferrini S., Agarwala M. and Turner K. (2017) Valuation for Natural Capital and Ecosystem Accounting. Synthesis report for the European Commission. Centre for Social and Economic Research on the Global Environment, University of East Anglia. Norwich. 
Bo Jellesmark Thorsen, Robert Mavsar, Liisa Tyrväinen, Irina Prokofieva and Anne Stenger (eds). (2014). The Provision of Forest Ecosystem Services. Volume II: Assessing cost of provision and designing economic instruments for ecosystem services. What Science Can Tell Us No. 5. European Forest Institute.

Bo Jellesmark Thorsen, Robert Mavsar, Liisa Tyrväinen, Irina Prokofieva and Anne Stenger (eds). (2014). The Provision of Forest Ecosystem Services. Volume I: Quantifying and valuing non-marketed ecosystem services. What Science Can Tell Us No. 5. European Forest Institute. http://dx.doi.org/10.13140/2.1.4390.4962.

C. Comberti, T.F. Thornton, V. Wyllie de Echeverria and T. Patterson. (2015). Ecosystem services or services to ecosystems? Valuing cultivation and reciprocal relationships between humans and ecosystems. Elsevier Ltd., Global Environmental Change, volume $34 \quad$ (2015) pp. 247-262. http://dx.doi.org/10.1016/j.gloenvcha.2015.07.007.

Daiju Narita, Mulugeta Lemenih, Yukimi Shimoda, and Alemayehu N. Ayana (2018). Economic accounting of ethiopian forests: A natural capital approach. Forest Policy and Economics 97 (2018) pp. 189-200. https://doi.org/10.1016/j.forpol.2018.10.002.

EU, IMF, OECD, UN and WB. (2009). System of National Accounts 2008. European Communities, International Monetary Fund, Organization for Economic Co-operation and Development, United Nations and World Bank. New York.

FAO. (2004). The state of Food Security in the World. Monitoring progress towards the World Food Summit and Millennium Development Goals. Food and Agriculture Organization of the United Nations Viale delle Terme di Caracalla, 00100 Rome, Italy.

FAO. (2014). Contribution of the forestry sector to national economies, 1990-2011. by Arvydas Lebedys and Yanshu Li. Forest Finance Working Paper FSFM/ACC/09. Forest Economics, Policy and Products Division Forestry Department, Food and Agriculture Organization of the United Nations. Rome, Italy.

FAO. (2016). Forestry Contribution to National Economy and Trade in Ethiopia, Kenya and Uganda. By Edward Kilawe and Didier Habimana. Addis Ababa, Ethiopia.

Hundessa Adugna. (2017). Contribution of Forest Production to GDP and Its Challenges in Oromia National Regional State, Ethiopia. Jurnal Ekonomi dan Studi Pembangunan (JESP), volume 9, No. 1 pp. 103-113. http://dx.doi.org/10.17977/um002v9i12017p102.

Katrina Mullan. (2014). The Value of Forest Ecosystem Services to Developing Economies. Center for Global Development (CGD) Working Paper. Washington, DC: Center for Global Development.

Louise Sing, Duncan Ray and Kevin Watts. (2015). Ecosystem services and forest management. Research Note. Forestry Commission publications: www.forestry.gov.uk/publications.

Masiero, M., Pettenella, D., Boscolo, M., Barua, S.K, Animon, I. \& Matta,.R. (2019). Valuing forest ecosystem services: a training manual for planners and project developers. Forestry Working Paper No. 11. Rome, FAO. 216 pp. Licence: CC BY-NC-SA 3.0 IGO.

MEA. (2005). Ecosystems and human well-being: the assessment series. Millennium Ecosystem Assessment (MEA). Washington, DC, Island Press.

MEFCC. (2016a). Ethiopia's Forest Level Submission to UNFCCC. Ministry Environment, Forest and Climate change of Ethiopia (MEFCC). Addis Ababa, Ethiopia.

MEFCC. (2016b). National Forest Sector Development Program, Ethiopia. Volume I: Program Pillars, Action Areas and Targets. Ministry of Environment Forest and Climate Change. Addis Ababa, Ethiopia.

N. Gregory Mankiw. (2009). Macroeconomics. Seventh Edition. Harvard University. Worth Publishers. 41 Madison Avenue. New York, NY 10010. www.worthpublishers.com.

Sisay Nune, Menale Kassie, and Eric Mungatana. (2010). Forest Resource Accounts for Ethiopia. Centre for Environmental Economics and Policy in Africa (CEEPA) of the University of Pretoria Springer. Pretoria, South Africa.

Söderqvist, T., Sundbaum, C., Folke, C., \& Mäler, K.-G. (2011). Bringing Ecologists and Economists Together: the Askö Meetings and Papers. Heidelberg. Retrieved from http://urn.kb.se/resolve?urn=urn:nbn:se:su:diva70111.

T. V. Ramachandra, Divya Soman, Ashwath D. Naik \& M. D. Subash Chandran. (2017). Appraisal of Forest Ecosystems Goods and Services: Challenges and Opportunities for Conservation. Journal of Biodiversity, Volume 8: No. 1, pp. 12-33. http://dx.doi.org/10.1080/09766901.2017.1346160.

UNDP Ethiopia. (2017). Assessment Socio-economic value of forest products for rural communities in Ethiopia. By Tesfaye Yimer. United Nations Development Programme (UNDP), United Nations Environment Programme (UNEP), UN-REDD Programme and Ministry of Environment, Forestry and Climate Change, Ethiopia. Addis Ababa, Ethiopia.

UNEP. (2016). The contribution of forests to national income in Ethiopia and linkages with REDD+. United Nations Environment Programme: Nairobi, Kenya.

United Nations. (2008). International Standard Industrial Classification of all Economic Activities Revision 4. New York: United Nations Department of Economic and Social Affairs, Statistics Division. 
United Nations. (2014). System of Environmental Economic Accounting - Central Framework 2012. SEEA Central Framework. United Nations, United Nations European Commission, Food and Agriculture Organization of the United Nations, Organization for Economic Co-operation and Development and World Bank Group. New York.

United States Environmental Protection Agency. (2015). National Ecosystem Services classification System (NESCS): Framework Design and Policy Application. EPA-800-R-15-002. United States Environmental Protection Agency, Washington, DC. 